\title{
Evaluation of Different Weed Management Practices on Yield attributes and Yield of Transplanted Rice
}

\author{
G. Manisankar*, T. Ramesh and S. Rathika \\ Department of Agronomy, Anbil Dharmalingam Agricultural College and Research Institute, \\ Tamil Nadu Agricultural University, Trichy - 620027, India \\ *Corresponding author
}

\section{Keywords}

Weed management, transplanted rice, yield attributes and yield, pre plant application, glyphosate, glufosinate ammonium, halosulfuron methyl

Article Info

Accepted: 12 April 2021 Available Online: 10 May 2021
A B S T R A C T

A field experiment was carried out at Department of Agronomy, Anbil Dharmalingam Agricultural College and Research Institute, Trichy during Rabi, 2018 to study the effect of different weed management practices on yield attributes and yield of transplanted rice. The experiment was laid out in split plot design with four main plot and five sub plot treatments and replicated thrice. The experimental plot size was 20 $\mathrm{m}^{2}$. Main plot treatments were pre plant application of herbicides namely, glyphosate $2.5 \mathrm{~kg} \mathrm{ha}^{-1}$, glufosinate ammonium $1.0 \mathrm{~kg} \mathrm{ha}^{-1}$,halosulfuron methyl $67.5 \mathrm{~g} \mathrm{ha}^{-1}$ and control. Sub plot treatments consisted of different weed management practices in transplanted rice namely, pre emergence application of bensulfuron methyl + pretilachlor $660 \mathrm{~g} \mathrm{ha}^{-1}$ on $3 \mathrm{DAT}+$ one hand weeding on $45 \mathrm{DAT}$, post emergence application of bispyribac sodium $25 \mathrm{~g} \mathrm{ha}^{-1}$ on $15 \mathrm{DAT}+$ one hand weeding on $45 \mathrm{DAT}$, application of bensulfuron methyl + pretilachlor $660 \mathrm{~g} \mathrm{ha}^{-1}$ on $3 \mathrm{DAT}+$ bispyribac sodium $25 \mathrm{~g} \mathrm{ha}^{-1}$ on $25 \mathrm{DAT}$, hand weeding twice at 25 and 45 DAT and unweeded control. Pre plant herbicides sprayed 15 days before puddling. The rice variety TRY 3 was grown during the course of investigation. Pre plant application of glyphosate 2.5 $\mathrm{kg} \mathrm{ha}^{-1}$ recorded significantly higher yield attributes and yield viz., productive tillers $\left(350 \mathrm{~m}^{-2}\right)$, Panicle length $(24.4 \mathrm{~cm})$, filled grains $\left(153\right.$ panicle $\left.^{-1}\right)$, total grains (171 panicle $\left.{ }^{-1}\right)$, higher grain yield $\left(4232 \mathrm{~kg} \mathrm{ha}^{-1}\right)$, straw yield $\left(6986 \mathrm{~kg} \mathrm{ha}^{-1}\right)$ and harvest index $(0.38 \%)$ than halosulfuron methyl and control. These results are closely followed by glufosinate ammonium $1.0 \mathrm{~kg} \mathrm{ha}^{-1}$. Among the weed management practices fallowed in transplanted rice, post emergence application of bispyribac sodium $25 \mathrm{~g} \mathrm{ha}^{-1}+$ hand weeding on 45 DAT registered significantly higher yield attributes and yield Viz., productive tillers $\left(338 \mathrm{~m}^{-2}\right)$, Panicle length $(24.7 \mathrm{~cm})$, filled grains $\left(159\right.$ panicle $\left.^{-1}\right)$, total grains $\left(179\right.$ panicle $\left.^{-1}\right)$, higher grain yield $\left(4327 \mathrm{~kg} \mathrm{ha}^{-1}\right)$ and harvest index $(0.39 \%)$ than others. Pre emergence application of bensulfuron methyl + pretilachlor $660 \mathrm{~g} \mathrm{ha}^{-1}+$ post emergence application of bispyribac sodium $25 \mathrm{~g} \mathrm{ha}^{-1}$ on 25 DAT significantly registered higher straw yield of $7174 \mathrm{~kg} \mathrm{ha}^{-1}$ over unweeded control. 


\section{Introduction}

Rice (Oryza sativa L.) is the staple food for more than 60 per cent of the world population and its cultivation secures a livelihood for more than two billion people. In India, rice is grown in an area of 43.79 million hectare with a production of 112.91 million tonnes and an average productivity of 2.5 tonnes hectare ${ }^{-1}$ (Anonymous, 2018). In Tamil Nadu, rice is grown in an area of 1.85 million hectares with a production of 6.95 million tonnes and an average productivity of 3.7 tonnes hectare ${ }^{-1}$ (Anonymous, 2019).

Weeds are the major biotic constraint to reduce the rice productivity in worldwide. In transplanted rice, about $60 \%$ of the weeds emerge in the period of one week to one month after transplanting. These emerging weeds are competing with rice during effective tillering stage and decline the quantity of panicles leads to reduction in grain yield (Soe thura, 2010). In transplanted rice, $45-51 \%$ yield reduction caused by weeds (Veeraputhiran and Balasubramanian, 2013).

In Rabi season rice (Sep - Jan), where one rice crop is being grown per year and rest of the period, the fields are left as fallow, weeds grown enormously during off season and poses serious threat in reducing the grain yield of rice. Rainfall during August-September months and soaking of main field during nursery period causes more weeds infestation and multiplication. Cyperus rotundus is one of the dominant weeds of sodic soil causes difficulty in land preparation for rice cultivation (Revathi et al., 2017).

In addition, regeneration of Cyperus rhizomes and weeds infestation occur during early growth stages of rice due to improper land leveling and alternate wetting and drying irrigation pattern causes more weeds growth, which leads to reduction in yield of rice.
Weed management can be achieved either application of pre emergence or post emergence or combination of both or manual weeding. Hand weeding is an effective method of weed management in transplanted rice, increasing labourer cost and scarcity of labourer during critical period of agricultural operation lead to the search for alternative methods. Hence, pre plant application of herbicide can be used for controlling the emerged weeds particularly Cyperus before transplanting which causes easy land preparation and less weeds in the rice field. Chemical method was most effective, economical way of weed management (Suresh kumar and Durairaj, 2016).

Pre plant application of herbicide provide weed free condition during initial stage because it arrest the germination of weeds. In transplanted rice, later emerged weed makes serious problem during critical period of crop weed competition. Hence, use of pre emergence or post emergence herbicides or combination of both is essential for reduce crop weed interference. It is highly essential to control the weeds in transplanted rice through sequential application of herbicides. Very fewer studies have been done on yield attributes and yield transplanted rice using sequential application of herbicides. Hence, present experiment has been carried out to evaluate the sequential herbicide application on yield attributes and yield of transplanted rice.

\section{Materials and Methods}

A field experiment was conducted at Department of Agronomy, Anbil Dharmalingam Agricultural College and Research Institute, Tamil Nadu Agricultural University, Tiruchirappalli during Rabi, 2018. The total rainfall received during cropping season was $234 \mathrm{~mm}$ in 12 rainy days. The mean maximum and minimum temperature 
prevailed during the cropping period were $31.8^{\circ} \mathrm{C}$ and $22.7^{\circ} \mathrm{C}$, respectively. The mean relative humidity was 87 and $61 \%$ during forenoon and afternoon, respectively. The mean bright sunshine hours, evaporation and wind velocity were 6.3 hours day ${ }^{-1}, 3.3 \mathrm{~mm}$ day $^{-1}$ and $3.8 \mathrm{~km} \mathrm{hr}^{-1}$, respectively.

The soil of the experimental field was alkaline in nature (pH-9.1), sandy clay loam in texture, moderately drained and classified as Vetric Ustropept. The experimental soil was low in available nitrogen $\left(112.9 \mathrm{~kg} \mathrm{ha}^{-1}\right)$, medium in available phosphorus (14.2 $\left.\mathrm{kg} \mathrm{ha}^{-1}\right)$ and high in available potassium $\left(288.4 \mathrm{~kg} \mathrm{ha}^{-1}\right)$.

The experiment was laid out in split plot design with four main plot and five sub plot treatments and replicated thrice. The experimental plot size was $20 \mathrm{~m}^{2}$. Main plot treatments were pre plant application of herbicides namely glyphosate $2.5 \mathrm{~kg} \mathrm{ha}^{-1}$,

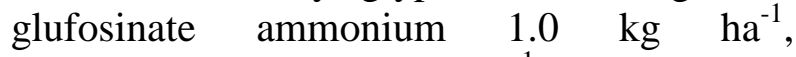
halosulfuron methyl $67.5 \mathrm{~g} \mathrm{ha}^{-1}$ and control.

Sub plot treatments consisted of different weed management practices in transplanted rice namely, pre emergence application of bensulfuron methyl + pretilachlor $660 \mathrm{~g} \mathrm{ha}^{-1}$ on 3 DAT + one hand weeding on 45 DAT, post emergence application of bispyribac sodium $25 \mathrm{~g} \mathrm{ha}^{-1}$ on 15 DAT + one hand weeding on 45 DAT, application of bensulfuron methyl + pretilachlor $660 \mathrm{~g} \mathrm{ha}^{-1}$ on 3 DAT + bispyribac sodium $25 \mathrm{~g}^{-1} \mathrm{ha}^{-1}$ on 25 DAT, hand weeding twice at 25 and 45 DAT and unweeded control.

Pre plant herbicides sprayed 15 days before puddling. The rice variety TRY 3 was grown during the course of investigation. All the agronomic practises and plant protection measures were adopted as per the recommended package of Tamil Nadu Agricultural University, Coimbatore (CPG, 2012).

\section{Yield attributes and yield}

Yield parameters and yield were recorded at harvest.

\section{Productive tillers}

Productive tillers were counted using quadrates at randomly from each net plot and expressed in numbers per $\mathrm{m}^{2}$.

\section{Panicle length}

Panicle length was measured in randomly selected ten panicles and denoted as $\mathrm{cm}$.

\section{Total grains panicle ${ }^{-1}$}

Randomly selected ten panicles used for counting total grains panicle ${ }^{-1}$ and denoted as total grains panicle ${ }^{-1}$.

\section{Number of filled grains panicle ${ }^{-1}$}

Number of filled grains panicle ${ }^{-1}$ were counted from the randomly selected ten panicles and denoted as filled grains panicle ${ }^{-1}$.

\section{Test weight}

Thousand filled grains were counted and weighed at $14 \%$ moisture and denoted in $\mathrm{g}$.

\section{Grain yield}

Grains harvested from the net plot area was thrashed, cleaned, sun dried and weighed at 14 $\%$ moisture and expressed as $\mathrm{kg} \mathrm{ha}^{-1}$.

\section{Straw yield}

Paddy straw from net plot was sun dried, weighed and denoted as $\mathrm{kg} \mathrm{ha-}{ }^{1}$. 


\section{Harvest Index (HI)}

$\mathrm{HI}(\%)$

$=$ Grain yield $\left(\mathrm{Kg} \mathrm{ha}^{-1}\right) /$ Biological yield $\left(\mathrm{Kg} \mathrm{ha}^{-1}\right)$

Where, Biological yield $=$ Grain yield $\left(\mathrm{Kg} \mathrm{ha}^{-1}\right)+$ Straw yield $\left(\mathrm{Kg} \mathrm{ha}^{-1}\right)$

\section{Statistical analysis}

The data were statistically analysed following the procedure given by Panse and Sukhatme (1967) for split plot design. CD at $5 \%$ probability was calculated.

\section{Weed flora}

Common weed species observed in the field during the course of investigation were Echinochloa colona (L.), Cynodon dactylon (L.) in grasses, Cyperus rotundus (L.) in sedges and Eclipta alba (L.), Euphorbia prostrata (L.), Lippia nodiflora (L.) in broad leaved weeds (Fig 1). Before spraying of pre plant herbicides, sedges $(71 \%)$ was found to be the predominant category followed by grasses $(18 \%)$ and broad leaved weeds (BLW) (11\%). Cyperus rotundus is one of the dominant weed in sodic soil environment and similar weed species have been found in transplanted rice under sodic soil (Revathi et al., 2017). In transplanted rice, grasses (65.4 $\%$ ) was the dominant weed, followed by sedges $(30.1 \%)$ and BLW $(4.5 \%)$ at 60 DAT in absolute control. This might be due to pre plant application of glyphosate and glufosinate ammonium completely destroyed the weeds before transplanting and also reduced the weeds germination as well as re-growth of Cyperus in rice field.

\section{Yield attributes}

All the weed management treatments showed significant variation in the yield attributes of transplanted rice (Table 1). Spraying of glyphosate $2.5 \mathrm{~kg} \mathrm{ha}^{-1}$ produced significantly more productive tillers $\left(350 \mathrm{~m}^{-2}\right)$, Panicle length $(24.4 \mathrm{~cm})$, filled grains $\left(153\right.$ panicle $\left.^{-1}\right)$ and total grains (171 panicle $\left.{ }^{-1}\right)$ than halosulfuron methyl and control. Application glyphosate $2.5 \mathrm{~kg} \mathrm{ha}^{-1}$ at 15 days before puddling controlled all the weeds including Cyperus, the most problematic weed of wet land rice. Further, complete drying and incorporation of weeds during puddling would have reduced the weed germination, led to very few weeds encountered after transplanting of rice. In addition, lower nutrient removal by weeds and higher nutrient uptake by crop at early stages improved the plant growth parameters and ultimately higher yield attributes. These findings are in accordance with findings of Parthipan and Ravi (2016). However, it was comparable with glufosinate ammonium $1.0 \mathrm{~kg} \mathrm{ha}^{-1}$. Application halosulfuron methyl $67.5 \mathrm{~g} \mathrm{ha}^{-1}$ resulted significantly lesser productive tillers $\left(281 \mathrm{~m}^{-}\right.$ $\left.{ }^{2}\right)$, Panicle length $(22.5 \mathrm{~cm})$, filled grains $(137$ panicle $\left.^{-1}\right)$, total grains $\left(161\right.$ panicle $\left.^{-1}\right)$ and was comparable with control.

Among the sub plot treatments, post emergence application of bispyribac sodium $25 \mathrm{~g} \mathrm{ha}^{-1}+$ hand weeding on 45 DAT resulted significantly more productive tillers $\left(338 \mathrm{~m}^{-2}\right)$, Panicle length $(24.7 \mathrm{~cm})$, filled grains (159 panicle $^{-1}$ ), total grains $\left(179\right.$ panicle $\left.^{-1}\right)$ and was comparable with pre emergence application of bensulfuron methyl + pretilachlor $660 \mathrm{~g} \mathrm{ha}^{-1}+$ post emergence application of bispyribac sodium $25 \mathrm{~g} \mathrm{ha}^{-1}$ on 25 DAT and hand weeding twice at 25 and 45 DAT. Bispyribac sodium as a post emergence herbicide, controlled broad spectrum of weeds including grasses, sedges and broadleaved weeds through acetolactate synthase mode of action, during critical period of crop weed competition. Second flush of weeds may removed by manual weeding at 45 DAT resulted in lesser crop weed competition, increased nutrient availability to crop favored 
better source sink relationship and ultimately more of yield attributes. Bensulfuron methyl + pretilachlor $660 \mathrm{~g} \mathrm{ha}^{-1}+$ hand weeding on 45 DAT recorded lesser number of productive tillers $\left(314 \mathrm{~m}^{-2}\right)$, Panicle length $(22.6 \mathrm{~cm})$, filled grains (142 panicle $\left.^{-1}\right)$ and total grains (162 panicle $\left.^{-1}\right)$. Unweeded control obtained significantly lower number of yield attributes.

This might be due to poor interception of light as well as lesser nutrient available to plants resulted in poor photosynthesis and photochemical energy supply which ultimately affected the translocation of photosynthates to the developing grains (Mandhata singh and Singh, 2010).

Thousand grain weight of rice was not significantly differed with different pre plant as well as rice weed management practices.

\section{Yield}

Adoption of different weed control practices produced distinct variations in grain as well as straw yield of transplanted rice (Table 2). Among the pre plant herbicides, glyphosate $2.5 \mathrm{~kg} \mathrm{ha}^{-1}$ produced significantly higher grain yield $\left(4232 \mathrm{~kg} \mathrm{ha}^{-1}\right)$ and straw yield $(6986 \mathrm{~kg}$ $\mathrm{ha}^{-1}$ ) over halosulfuron methyl and control. The increment in grain and straw yields were mainly due to that application of glyphosate $2.5 \mathrm{~kg} \mathrm{ha}^{-1}$ at 15 days before puddling controlled all the weeds including Cyperus by inhibiting5-enolpyruvylshikimate-3-phosphate (EPSP) synthase pathway that required for protein synthesis. Further, complete drying and incorporation of weed during puddling would have reduced the weed germination resulted in lesser crop weed competition and higher weed control efficiency. These conditions favored better crop growth and yield parameters which ultimately increased the grain and straw yield of rice. These results are similar with findings of Veeraputhiran and Balasubramanian (2010), who reported that application of glyphosate at 15 days before transplanting registered higher grain and straw yields in rice. However, this was comparable with glufosinate ammonium $1.0 \mathrm{~kg} \mathrm{ha}^{-1}(4145$ and $6708 \mathrm{~kg} \mathrm{ha}^{-1}$ grain and straw yield, respectively). Glufosinate inhibited the activity of glutamine synthase, the enzyme that essential for conversion of glutamate plus ammonium to glutamine. Accumulation of ammonia in the plant, that leads to destroys cells directly and inhibits photosystem I and II reactions, caused complete drying of weeds including Cyperus within 7 days after application, resulted in less weed density and competition favored better crop growth and yield. Halosulfuron methyl $67.5 \mathrm{~g} \mathrm{ha}^{-1}$ resulted significantly lower grain yield (3959 $\left.\mathrm{kg} \mathrm{ha}^{-1}\right)$ and straw yield $\left(6560 \quad \mathrm{~kg} \mathrm{ha}^{-1}\right)$ than glyphosate. The reason behind lesser grain yield was poor control of weeds particularly Cyperus rotundus. Halosulfuron methyl effectively control the Cyperus at 3-4 leaf stage only and in this experimental field, Cyperus was present in flowering to maturity stage. These findings are in accordance with Mritunjaykumar (2018), who reported that foliar application of halosulfuron methyl $75 \%$ WG was given at 3-4 leaf stage of Cyperus rotundus for effective control. Lesser grain yield $\left(3565 \mathrm{~kg} \mathrm{ha}^{-1}\right)$ and straw yield $(6337 \mathrm{~kg}$ $\mathrm{ha}^{-1}$ ) was registered with control plot.

Weed management practices imposed in transplanted rice significantly altered the grain yield and straw yield. Among the post plant weed management practices, post emergence application of bispyribac sodium $25 \mathrm{~g} \mathrm{ha}^{-1}+$ hand weeding on 45 DAT registered significantly more grain yield (4327 $\mathrm{kg} \mathrm{ha}^{-1}$ ) over unweeded control. However, this was comparable with bensulfuron methyl + pretilachlor $660 \mathrm{~g} \mathrm{ha}^{-1}+$ bispyribac sodium 25 $\mathrm{g} \mathrm{ha}^{-1}$ on 25 DAT (4299 kg ha ${ }^{-1}$ ), hand weedingtwice at 25 and 45 DAT (4187 kg ha $\left.{ }^{1}\right)$ and pre emergence application of bensulfuron methyl + pretilachlor $660 \mathrm{~g} \mathrm{ha}^{-1}$ on $3 \mathrm{DAT}+$ hand weeding on $45 \mathrm{DAT}(4143$ $\left.\mathrm{kg} \mathrm{ha}^{-1}\right)$. 
Table.1 Evaluation of different weed management practices on yield attributes of transplanted rice.

\begin{tabular}{|c|c|c|c|c|c|}
\hline Treatments & $\begin{array}{l}\text { Productive } \\
\text { tillers }\left(\mathbf{m}^{-2}\right)\end{array}$ & $\begin{array}{c}\text { Panicle } \\
\text { length }(\mathrm{cm})\end{array}$ & $\begin{array}{l}\text { Total grains } \\
\text { panicle }^{-1}\end{array}$ & $\begin{array}{l}\text { No. of filled } \\
\text { grains } \\
\text { panicle }^{-1}\end{array}$ & $\begin{array}{l}\text { Test weight } \\
\text { (g) }\end{array}$ \\
\hline \multicolumn{6}{|c|}{ Main plots (Pre plant herbicides) } \\
\hline M $_{1}$ - Glyphosate $2.5 \mathrm{~kg} \mathrm{ha}^{-1}$ & 350 & 24.4 & 171 & 153 & 24.5 \\
\hline 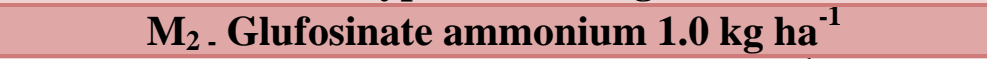 & 331 & 23.6 & 169 & 146 & 24.2 \\
\hline $\mathrm{M}_{3}$ - Halosulfuron methyl $67.5 \mathrm{~g} \mathrm{ha}^{-1}$ & 281 & 22.5 & 161 & 137 & 23.9 \\
\hline $\mathrm{M}_{4-}$ Control & 263 & 21.7 & 157 & 131 & 24.0 \\
\hline SEd & 8 & 0.64 & 3 & 4 & 0.40 \\
\hline $\mathrm{CD}(\mathrm{P}=\mathbf{0 . 0 5})$ & 20 & 1.58 & 8 & 9 & NS \\
\hline \multicolumn{6}{|c|}{ Sub plots (Weed management in rice) } \\
\hline $\begin{array}{c}\mathrm{S}_{1} \text { - PE bensulfuron methyl + pretilachlor } 660 \mathrm{~g} \mathrm{ha}^{-1} \\
+ \text { HW on } 45 \text { DAT }\end{array}$ & 314 & 22.6 & 162 & 142 & 24.3 \\
\hline $\mathrm{S}_{2}$. POE bispyribac sodium $25 \mathrm{~g} \mathrm{ha}^{-1}+\mathrm{HW}$ on 45 DAT & 338 & 24.7 & 179 & 159 & 24.6 \\
\hline $\begin{array}{c}\mathrm{S}_{3} \text { - PE bensulfuron methyl + pretilachlor } 660 \mathrm{~g} \mathrm{ha}^{-1} \\
+ \text { POE bispyribac sodium } 25 \mathrm{~g} \mathrm{ha}^{-1}\end{array}$ & 329 & 23.9 & 169 & 150 & 24.0 \\
\hline $\mathrm{S}_{4} . \mathrm{HW}$ on 25 and 45 DAT & 318 & 23.2 & 167 & 146 & 23.9 \\
\hline$S_{5}$. Unweeded control & 233 & 20.8 & 144 & 116 & 24.7 \\
\hline SEd & 10 & 0.55 & 6 & 6 & 0.41 \\
\hline $\mathrm{CD}(\mathrm{P}=\mathbf{0 . 0 5})$ & 21 & 1.12 & 13 & 13 & NS \\
\hline
\end{tabular}

* Interaction non-significant PE- Pre emergence POE- Post emergence HW- Hand weeding 
Fig.1 Weed flora of the experimental field.

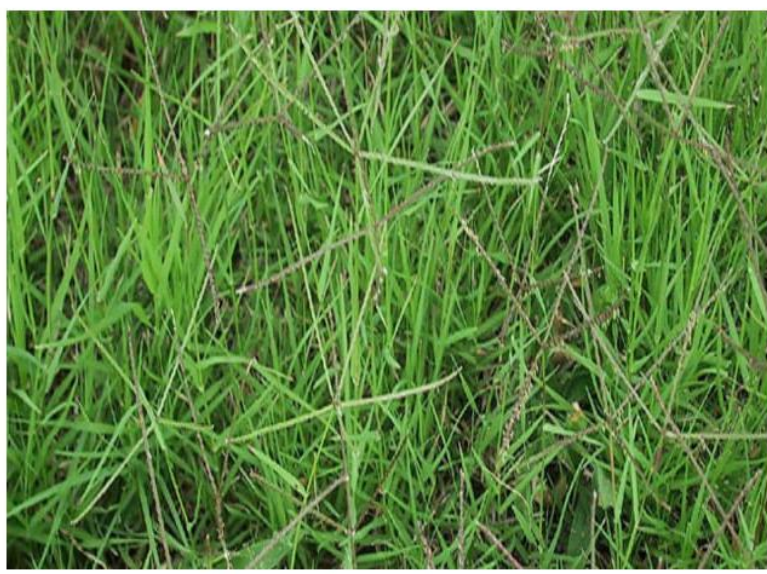

Cynodon dactylon

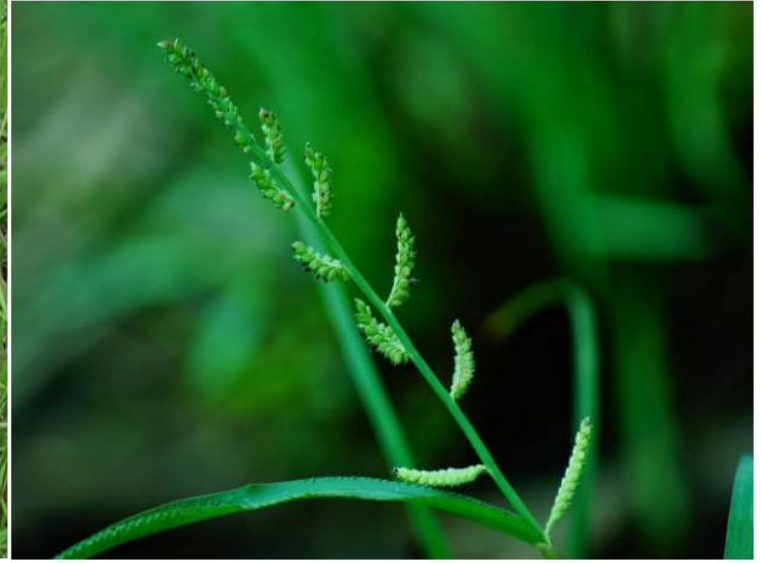

Echinochloa colona

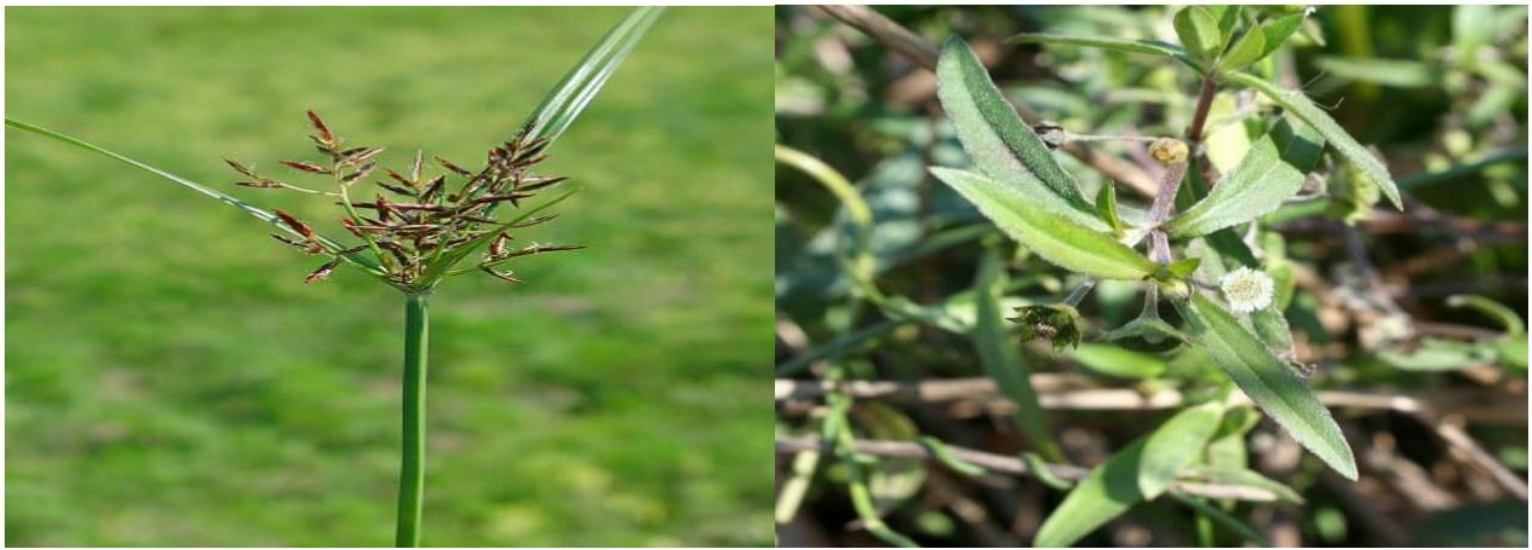

Cyperus rotundus

Eclipta alba

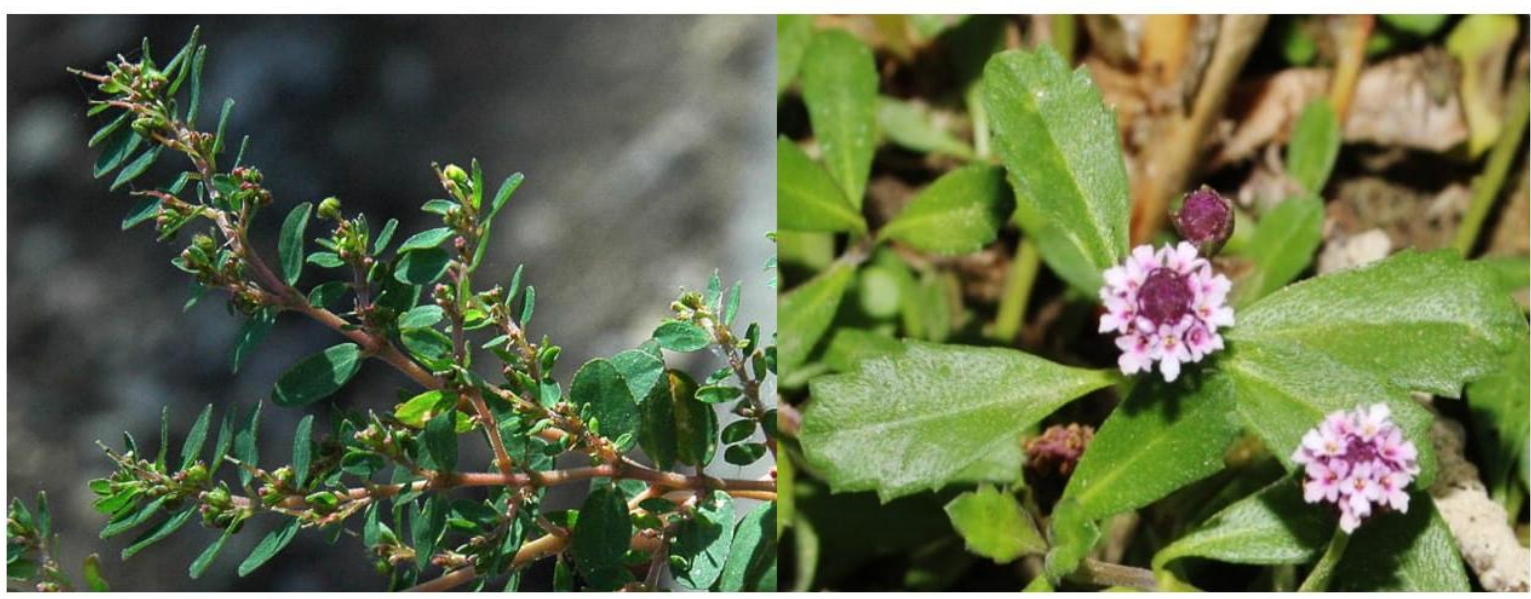

Euphorbia prostrata

Lippia nodiflora 
Table.2 Evaluation of different weed management practices on grain yield $\left(\mathrm{kg} \mathrm{ha}^{-1}\right)$, straw yield $\left(\mathrm{kg} \mathrm{ha}^{-1}\right)$ and harvest index $(\%)$ of transplanted rice.

\begin{tabular}{|c|c|c|c|}
\hline Treatments & Grain yield & Straw yield & Harvest index \\
\hline \multicolumn{4}{|c|}{ Main plots (Pre plant herbicides) } \\
\hline $\mathrm{M}_{1}$. Glyphosate $2.5 \mathrm{~kg} \mathrm{ha}^{-1}$ & 4232 & 6986 & 0.38 \\
\hline $\mathrm{M}_{2}$. Glufosinate ammonium $1.0 \mathrm{~kg} \mathrm{ha}^{-1}$ & 4145 & 6708 & 0.38 \\
\hline $\mathrm{M}_{3}$. Halosulfuron methyl $67.5 \mathrm{~g} \mathrm{ha}^{-1}$ & 3959 & 6560 & 0.37 \\
\hline $\mathrm{M}_{4-}$ Control & 3565 & 6337 & 0.36 \\
\hline SEd & 110 & 163 & 0.002 \\
\hline $\mathrm{CD}(\mathrm{P}=0.05)$ & 269 & 399 & 0.006 \\
\hline \multicolumn{4}{|c|}{ Sub plots (Weed management in rice) } \\
\hline $\begin{array}{c}\mathrm{S}_{1} \text { - PE bensulfuron methyl + pretilachlor } \\
660 \mathrm{~g} \mathrm{ha}^{-1}+\mathrm{HW} \text { on } 45 \mathrm{DAT}\end{array}$ & 4143 & 6963 & 0.37 \\
\hline $\begin{array}{c}\mathrm{S}_{2 .} \text { POE bispyribac sodium } 25 \mathrm{~g} \mathrm{ha}^{-1}+ \\
\text { HW on } 45 \text { DAT }\end{array}$ & 4327 & 6835 & 0.39 \\
\hline $\begin{array}{c}\mathrm{S}_{3 .} \text { PE bensulfuron methyl + pretilachlor } \\
660 \mathrm{~g} \mathrm{ha}^{-1}+\text { POE bispyribac sodium } 25 \mathrm{~g} \\
\text { ha }^{-1}\end{array}$ & 4299 & 7174 & 0.37 \\
\hline$S_{4}$. HW on 25 and 45 DAT & 4187 & 6850 & 0.38 \\
\hline$S_{5}$. Unweeded control & 2923 & 5416 & 0.35 \\
\hline SEd & 101 & 178 & 0.009 \\
\hline $\mathrm{CD}(\mathbf{P}=\mathbf{0 . 0 5})$ & 206 & 362 & 0.018 \\
\hline
\end{tabular}

The combination of two herbicides or one herbicide followed by one manual weeding controlled the weeds both first flush as well as later emerged weeds. This corroborating with the findings of Sureshkumar and Durairaj (2016). Bispyribac sodium $25 \mathrm{~g} \mathrm{ha}^{-1}$ interfered with production of a plant enzyme necessary for growth and development named acetolactate synthase (ALS) led to effectively controlled the emerged weeds during critical stages and maintain the crop free from crop weed competition resulted in lesser competition by weeds for nutrients, space and light ultimately increased plant height, tiller number, productive tillers, filled grains, DMP, LAI and finally grain yield. These results are in line with findings of Prashanth et al., (2015), who reported that post emergence application of bispyribac sodium at $25 \mathrm{~g} \mathrm{ha}^{-1}$ at 15 DAT recorded significantly higher grain yield in transplanted rice. Lesser grain yield $\left(2923 \mathrm{~kg} \mathrm{ha}^{-1}\right)$ was recorded under unweeded control.

Pre emergence application of bensulfuron methyl + pretilachlor $660 \mathrm{~g} \mathrm{ha}^{-1}+$ post emergence application of bispyribac sodium $25 \mathrm{~g} \mathrm{ha}^{-1}$ on 25 DAT significantly registered higher straw yield of $7174 \mathrm{~kg} \mathrm{ha}^{-1}$ than control and was statistically comparable with pre emergence application of bensulfuron methyl + pretilachlor $660 \mathrm{~g} \mathrm{ha}^{-1}+$ hand weeding on 45 DAT $\left(6963 \mathrm{~kg} \mathrm{ha}^{-1}\right)$, hand weeding twice at 25 and 45 DAT $\left(6850 \mathrm{~kg} \mathrm{ha}^{-1}\right)$ and post emergence application of bispyribac sodium $25 \mathrm{~g} \mathrm{ha}^{-1}+\mathrm{HW}$ on 45 DAT $\left(6835 \mathrm{~kg} \mathrm{ha}^{-1}\right)$. Unweeded control registered the lower straw yield of $5416 \mathrm{~kg} \mathrm{ha}^{-1}$. This is mainly because 
of severe crop weed competition during throughout the crop period. Same findings were reported by Parthipan and Subramanian (2013).

\section{Harvest index (HI)}

Harvest index of transplanted rice significantly influenced by pre plant application of herbicides and rice weed management practices (Table 2). Glyphosate $2.5 \mathrm{~kg} \mathrm{ha}^{-1}$ and glufosinate ammonium $1.0 \mathrm{~kg}$ ha $^{-1}$ registered significantly similar value of $\mathrm{HI}$ $(0.38 \%)$ over control. However, this was on par with halosulfuron methyl $67.5 \mathrm{~g} \mathrm{ha}^{-1}(0.37$ $\%)$. Control obtained lesser harvest index of $0.36 \%$. Among the sub plot treatments, post emergence application of bispyribac sodium $25 \mathrm{~g} \mathrm{ha}^{-1}+$ hand weeding on 45 DAT registered significantly higher harvest index $(0.39 \%)$ than control. However, it was statistically on par with hand weeding twice on 25 and 45 DAT $(0.38 \%)$, pre emergence application of bensulfuron methyl + pretilachlor $660 \mathrm{~g} \mathrm{ha}^{-1}+$ post emergence application of bispyribac sodium $25 \mathrm{~g} \mathrm{ha}^{-1}$ on 25 DAT $(0.37 \%)$ andpre emergence application of bensulfuron methyl + pretilachlor $660 \mathrm{~g} \mathrm{ha}^{-1}+$ hand weeding on 45 DAT $(0.37 \%)$. Unweeded control obtained lower harvest index $(0.35 \%)$.

Hence, it could be concluded from the field study, pre plant application of glyphosate 2.5 $\mathrm{kg} \mathrm{ha}^{-1}$ at 15 days before puddling followed by post emergence application of bispyribac sodium $25 \mathrm{~g} \mathrm{ha}^{-1}$ on $15 \mathrm{DAT}+$ hand weeding on 45 DAT found higher yield attributes and yield in transplanted rice.

\section{References}

Anonymous, 2018. Government of India (GoI). Agricultural Statistics at a Glance. Doctoral dissertation, Ministry of Agriculture. http://agricoop.gov.in/sites/default files/ agristatglance2018.pdf.

Anonymous, 2019. Area and production of cereals, Department of Economics and Statistics. https://eands.dacnet.nic.in/.

CPG, 2012. Crop Production Guide, Department of Agriculture, Govt. of Tamil Nadu, Chennai and Tamil Nadu Agricultural University, Coimbatore. pp. 4-43.

Kumar, M., 2018. Halosulfuron Methyl 75\% WG (Sempra) - A New Herbicide for the Control of Cyperus rotundus in Maize (Zea mays L.) Crop in Bihar. International Journal of Current Microbiology and Applied Sciences. 7 (3): 2319-7706.

Panse, V. G., and Sukhatme, P. V. 1967. Statistical methods for agricultural workers. Indian Council for Agricultural Research. New Delhi, India.

Parthipan, T., and Ravi, V. 2016. Productivity of transplanted rice as influenced by weed control methods. African Journal of Agricultural Research. 11 (6): 14451449.

Parthipan, T., and Subramanian, E. 2013. Rice and its Residual Effect on Succeeding Black gram. Journal of Agronomy. 12 (2): 99-103.

Prashanth, R., K. N. Kalyan murthy, M. Murali, C. Ramachandra and Sunil C. M. 2015. Growth and yield of transplanted rice as influenced by application of bispyribac sodium 10 SC a post-emergence herbicide. International Journal of Tropical Agriculture. 33 (1): 37-40.

Revathi, M., K. Annadurai and Chinnusamy, C. 2017. Effect of various pre and post emergence herbicides on crop yield and weed dynamics under different rice establishment methods in Sodic soil environment. International 
Journal of Chemical Studies. 5 (5): 1531-1536.

Singh, M., and Singh, R. P. 2010. Efficacy of herbicides under different methods of direct-seeded rice (Oryza sativa L.) establishments. Indian Journal of Agronomy. 80 (9): 815-819.

Soe thura., 2010. Evaluation of Weed Management practices in the System of Rice Intensification (SRI). M.Sc. (Ag.) Thesis, Department of
Agronomy, Yezin Agricultural University, Yezin, Nay Pyi Taw.

Suresh kumar, R., and Durairaj. 2016. Weed characters and indices of transplanted rice as influenced by different weed management practices. International Journal of Agriculture Sciences. 8 (51): 2221-2223.

Veeraputhiran, R., and Balasubramanian, R. 2013. Evaluation of bispyribac-sodium in transplanted rice. Indian Journal of Weed Science. 45 (1): 12-15.

\section{How to cite this article:}

Manisankar, G., T. Ramesh and Rathika, S. 2021. Evaluation of Different Weed Management Practices on Yield attributes and Yield of Transplanted Rice. Int.J.Curr.Microbiol.App.Sci. 10(05): 390-399. doi: https://doi.org/10.20546/ijcmas.2021.1005.046 